\title{
Determination of the concentration of Ce, La, Sm and Eu in a phosphogypsum stack, in Imbituba city, Santa Catarina, Brazil
}

\author{
Renata Coura Borges ${ }^{1+}$, Letícia Mombrini Marques² ${ }^{2}$ Cláudio Fernando Mahler ${ }^{1}$, Alfredo Victor Bellido Bernedo ${ }^{3}$ \\ ${ }^{1}$ Federal University of Rio de Janeiro (UFRJ), 2030-101 Horácio Macedo St, Rio de Janeiro, Rio de Janeiro, Brazil \\ 2 Federal Institute of Education, Science and Technology of Rio de Janeiro (IFRJ), Washington Luís Hw, Niterói, Rio de Janeiro, Brazil \\ ${ }^{3}$ Fluminense Federal University (UFF), 9 Miguel de Frias St, Niterói, Rio de Janeiro, Brazil \\ + Corresponding author: Renata Coura Borges, e-mail address: renatacouraborges@hotmail.com
}

\section{ARTICLE INFO}

Article history:

Received: February 05, 2018

Accepted: September 07, 2018

Published: October 07, 2018
Keywords:

1. phosphogypsum;

2. geoprocessing;

3. rare-earth elements.
ABSTRACT: Phosphate fertilizer industry produces phosphoric acid from phosphate rocks, and as a byproduct, it produces phosphogypsum, also known as agricultural gypsum. This material was stocked in openair stacks near the producing units. In order to determine levels of rareearth elements in phosphogypsum stacks, located in Imbituba, Brazil, samples of 2000 grams of phosphogypsum were collected in nine different points in stack 1 . The concentration of rare-earth elements was determined through neutron activation analysis and results indicate significant values of rare-earth elements in the phosphogypsum from Imbituba, when compared to the values of the Earth's crust.

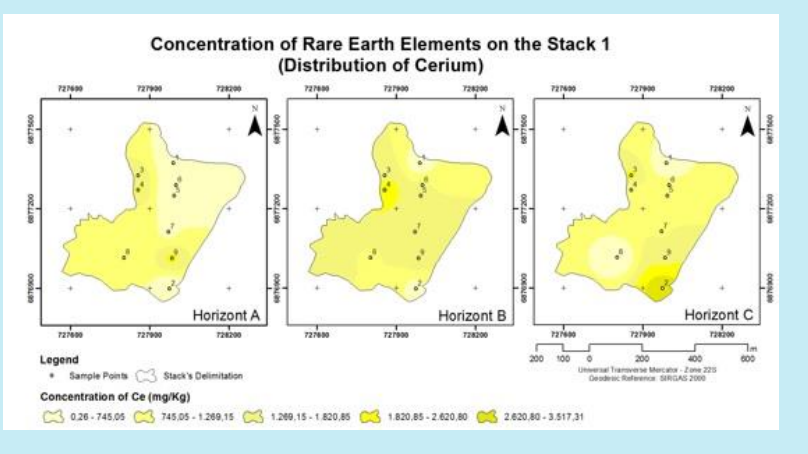

inhaling particles in suspension. Most of rare-earth elements, which are ingested, were excrete, although a short part can enter the bloodstream and accumulate in different parts of human body per ion exchange processes ${ }^{2}$.

An extensive volume of phosphogypsum generated annually by phosphoric acid production industries in world has been receiving attention of radiological and environmental protection agencies. In the Brazilian state of Santa Catarina, there is a stack of the material, located in the city of Imbituba, south of the state capital, Florianopolis. This material is currently commercialized and applied in apple and soybean crops. Some studies with Brazilian phosphogypsum have already been performed. However, there are no studies on phosphogypsum from this Brazilian State, and specially, on its toxicity by rare-earth elements.
Rare-earth elements can enter into human organism by ingesting contaminated food and 
This work aimed to quantify the presence of rare-earth elements (Sm, La, Ce, Eu) in phosphogypsum of Imbituba - Santa Catarina.

\section{Materials and methods}

\subsection{Study site}

Georeferenced samples of the PG (phosphogypsum) studied were collected in nine points in PG stack 1 (Figure 1), in the city of Imbituba, southern coast of Brazilian state of Santa Catarina ( $28^{\circ} 13^{\prime} 17^{\prime \prime} \mathrm{S}$ and $\left.48^{\circ} 38^{\prime} 21^{\prime \prime} \mathrm{W}\right)$. In addition, samples were collected in the Referenced Area (AR), with the purpose of comparison related to the chemical composition of the local soil without human interference (background value).

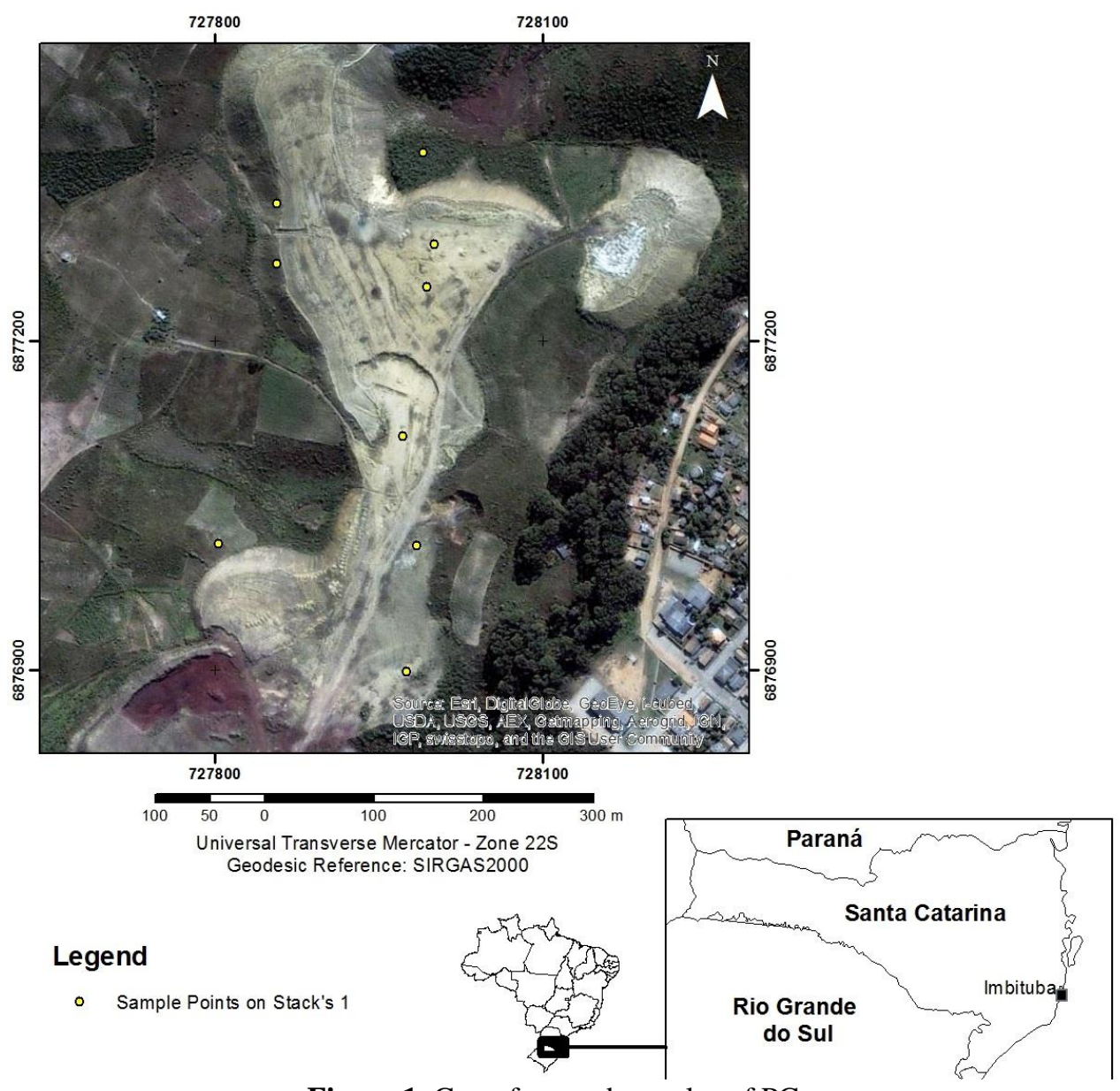

Figure 1. Georeferenced samples of PG.

\subsection{Sample collection and preparation}

Sampling procedures were managed in accordance to the Brazilian Association of Technical Standards (ABNT) ${ }^{3}$. The samples were collected in Engessul/Imbituba-SC, in May of 2008. The sampling procedures consisted on sample extraction, at different depths: $0-0.20 \mathrm{~m}$ (horizon A), $0.20-1 \mathrm{~m}$ (horizon B) and $1-2 \mathrm{~m}$ (horizon $\mathrm{C}$ ) with the purpose of evaluation of the distribution of chemical elements according to the stack depth. The samples composed of 2000 grams of phosphogypsum in each depth were conditioned in plastic bags previously identified and transported to the laboratory for posterior analysis. The soil samples followed the same procedures applied to the phosphogypsum.

All PG and soil samples were identified, grounded with a $2 \mathrm{~mm}$ mesh sieve at ambient temperature, to achieve a fine powder, and finally oven dried to constant weight. 


\subsection{Determination of rare-earth elements in the samples}

To determine the levels of rare-earth elements in phosphogypsum and soil, the neutron activation analysis method was applied. Powder samples were homogenized in an agate mortar, individually. Around $200 \mathrm{mg}$ of each sample was packed in polyethylene capsules using a four-decimal-placegraduated analytical balance. Capsules were sealed using a soldering tool with a graphite tip. Samples were irradiated for four hours in a thermal neutron flux of $10^{13} \mathrm{n} \mathrm{cm}^{-2} \mathrm{~s}^{-1}$ in the IEA-R1 nuclear reactor at Institute of Nuclear and Energetic Research (IPEN), São Paulo city, Brazil. In addition, "control" polyethylene capsules were also irradiated.

The standard used was the San Joaquin Soil (NIST 2709), that was prepared in the same way as samples with the view to guarantee the same geometries. To assess the data consistence and to guarantee the accuracy and reproducibility of the analysis, to each set of ten samples, one "control" sample and three samples of reference materials were analyzed.

The elements determined by this technique were $\mathrm{Sm}, \mathrm{Eu}, \mathrm{La}$ and $\mathrm{Ce}$.

\subsection{Statistical Analysis}

Owing to the complexity and variability normally observed in environmental studies, it is common the use of multivariate statistical methods to differentiate and identify natural levels of heavy metals from anthropogenic contamination. With the view to verify parameters that contribute with the characterization and how they were related with the methods used, cluster analysis was performed using STATISTICA 7 software (StatSoft Inc.).

\section{Results and discussion}

\subsection{Concentration of rare-earth elements}

The REE (rare-earth elements) in phosphogypsum derive by its raw material (phosphate rocks). There were two kinds of phosphate rocks: the sedimentary and igneous rock. The ore matrix used in the acid production process is the source of REE in the phosphogypsum. Phosphogypsum generated in Imbituba-SC was composed by phosphate rocks from igneous origins. Stack 1 was formed by igneous phosphate ores from Araxá - MG.

Table 1 presents rare-earth concentration values found in phosphogypsum analyzed in present study.

Table 1. Concentration (mean \pm standard deviation $\mathrm{mg} \mathrm{kg}^{-1}$ ) of REE from phosphogypsum in samples from other sources.

\begin{tabular}{c|c|c|c|c|c}
\hline Element & Russia $^{4}$ & Brazil $^{5}$ & Brazil $^{6}$ & Brazil $^{7}$ & Stack 1 \\
\hline $\mathrm{Ce}$ & 1600 & 2574 & 956 & 1730 & $1233 \pm 326$ \\
\hline $\mathrm{La}$ & 1050 & 1300 & 1017 & 973 & $27 \pm 4$ \\
\hline $\mathrm{Eu}$ & 30.4 & 36 & 26 & 29 & $36 \pm 3$ \\
\hline $\mathrm{Sm}$ & 76 & 149 & 123 & 85 & $70 \pm 12$ \\
\hline
\end{tabular}

Results showed that for Ce there were no large variations in the concentration, whereas La has a lower concentration in relation to those found by other authors. Eu and Sm present values close to those found in phosphogypsum from other regions. The summation $(\Sigma)$ of the total concentration of the REE (Ce, $\mathrm{La}, \mathrm{Eu}$ and $\mathrm{Sm}$ ) in the studied phosphogypsum was $1366.3 \mathrm{mg} \mathrm{kg}^{-1}$.
Figures 2, 3, 4 and 5 show the distribution of REE in relation to the depth in phosphogypsum of Imbituba.

Figure 2 presents Cerium $(\mathrm{Ce})$ results. In the Earth's crust, the mean concentration of $\mathrm{Ce}$ is 66 $\mathrm{mg} \mathrm{kg}^{-1}$, and in Chinese soils, the average concentration found in eight different types of soils was $86 \mathrm{mg} \mathrm{kg}^{-1} 8$. In Dutch soils, the maximum allowable concentration for Ce is $53 \mathrm{mg} \mathrm{kg}^{-1}$. 
There are no established guidelines values for this element in Brazil. Although, in this study, stack 1 has Ce values much higher than the allowed.

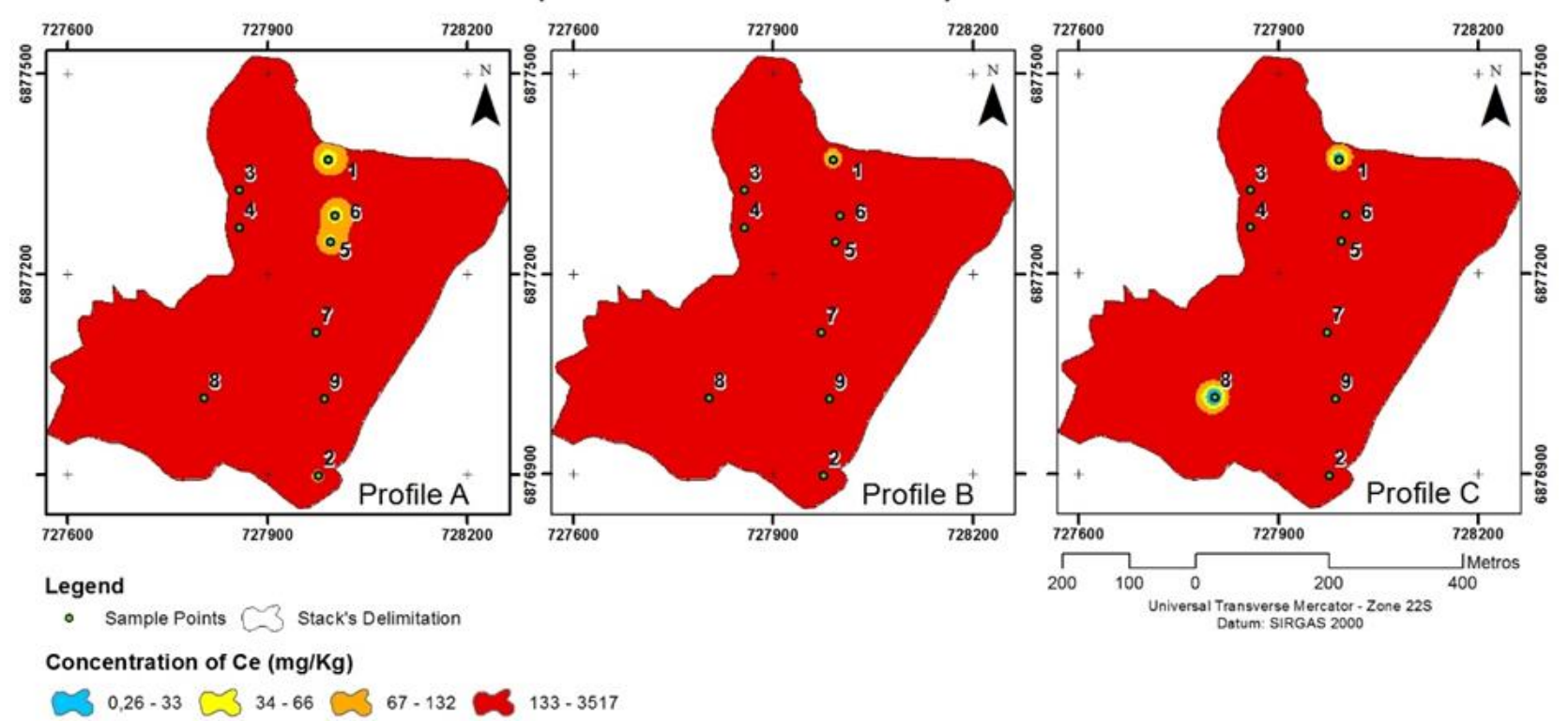

Figure 2. Distribution of Cerium on the stack 1.

According to Lapido-Loureiro et al. (2008) ${ }^{10}$, apatite, along with its varieties, form a relevant group of minerals. The $\mathrm{Ca}^{2+}$ can be replaced, principally, by rare-earth element light in igneous apatite and rare-earth element heavy in sedimentary origin. The results confirm this data, since stack 1 was formed by igneous rocks that were enriched with Cerium.
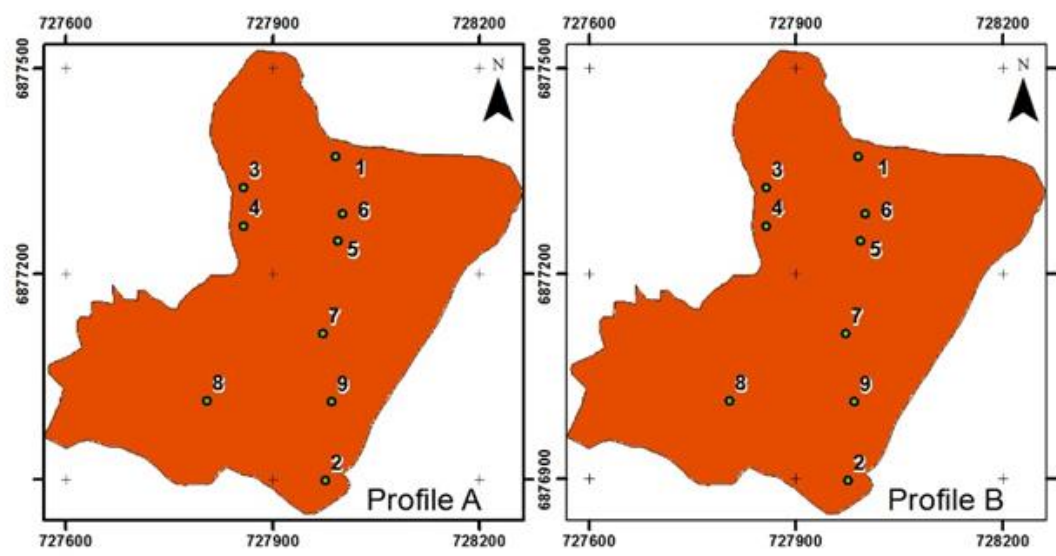

Legend

$$
\begin{aligned}
& \text { - Sample Points } 3 \text { Stack's Delimitation } \\
& \text { Concentration of Eu }(\mathrm{mg} / \mathrm{Kg}) \\
& \text { 3 } 0,5-2,14 \backsim 2,15-4,28 \backsim 4,291-6,42 \bigcirc 6,43 \cdot 45,4
\end{aligned}
$$

Comparing the values of $\mathrm{Ce}$ in igneous phosphate ores ${ }^{11}$, the concentration in stack 1 was in the range for the apatite in Norway (494.4$5352.9 \mathrm{mg} \mathrm{kg}^{-1}$ ), which confirms, again, the high concentration of REE in igneous rocks.

Figure 3. Distribution of Europium on the stack 1.

Figure 3 presents results for Europium (Eu). Eu is an element not found in nature as a free element and it is difficult its separation. The oxidation states are +3 and +2 and Eu was found in ores containing small amounts of all REE. In the Earth's crust, the mean concentration of Europium is about $2.14 \mathrm{mg}$ 
$\mathrm{kg}^{-1}{ }^{12}$. The average value obtained in stack 1 was $35 \mathrm{mg} \mathrm{kg}^{-1}$, higher than the determined for the crust and soil, but still in the concentration range found in igneous phosphate rocks $21.5-73.7^{11}$.

Evaluating the Eu concentration, according to the depths, it is possible to observe that the values decreased as the depth increased; that is, the horizons $\mathrm{B}$ and $\mathrm{C}$ presented lower concentration of the element.

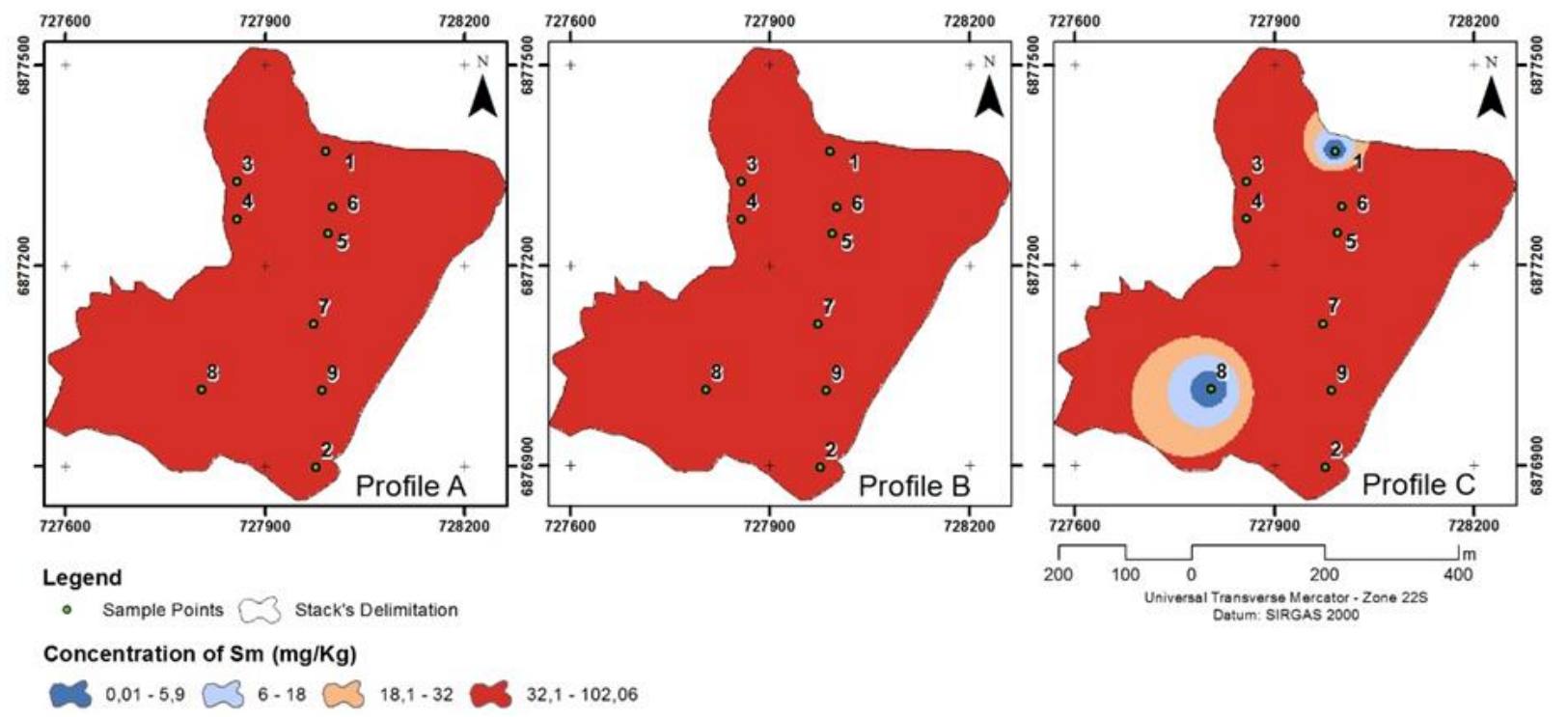

Figure 4. Distribution of Samarium on the stack 1.

Figure 4 presents results for Samarium (Sm). In stack 1, the average concentration of $\mathrm{Sm}$ found in phosphogypsum was $70 \mathrm{mg} \mathrm{kg}^{-1}$, less than mentioned by Ihlen et al. (2014) ${ }^{11}$, that found a concentration in the range of $86.3-323.3 \mathrm{mg} \mathrm{kg}^{-1}$ in igneous phosphate rocks. Presumably, this is related to the redistribution of $\mathrm{Sm}$ that has undergone chemical processing of phosphate rock.

Noticing the concentration over the depth: surface samples showed the highest concentration of this element and samples from the third depth, the lowest level.

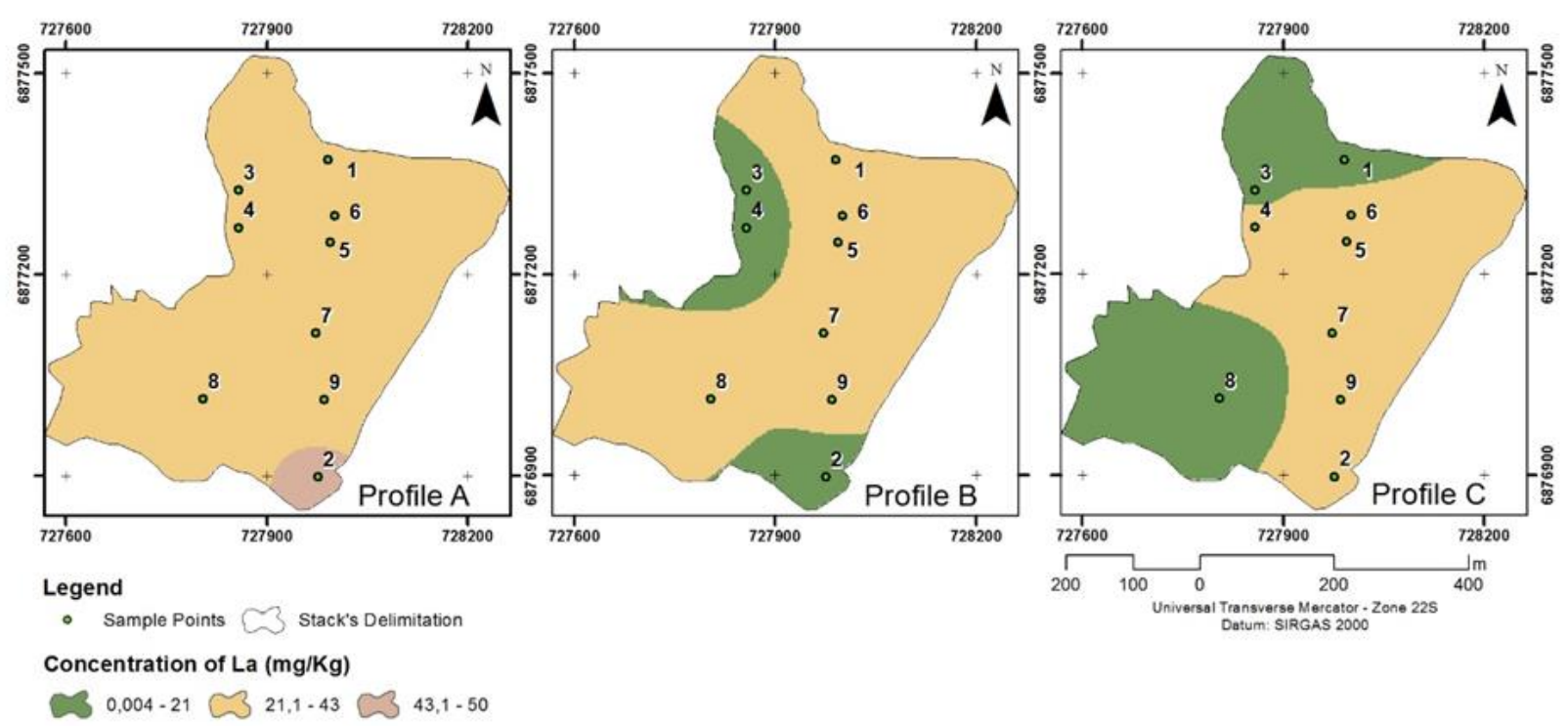

Figure 5. Distribution of Lanthanum on the stack 1. 
Figure 5 shows results for Lanthanum (La). In the Earth's crust, the mean value found was $43 \mathrm{mg}$ $\mathrm{kg}^{-113}$. Concentration found to $\mathrm{La}$, in samples from stack 1, were considered intermediate, when compared to the values determined for igneous rocks and below, when compared to the global average. Furthermore, few samples of phosphogypsum collected in the second and third depth of the stack 1 showed the maximum concentration for La.
It was observed that $\mathrm{La}, \mathrm{Eu}$ and $\mathrm{Sm}$ underwent little variation with depth, and $\mathrm{Ce}$, in some points, presented a great variation; this is because REE in phosphogypsum samples were associated to the formation of carbonates, fluorides, sulfates and phosphates of these elements ${ }^{8}$.

The experimental results and the certified values are in Table 2.

Table 2. Concentration (mean \pm standard deviation $\mathrm{mg} \mathrm{kg}^{-1}$ ) of REE from different literatures, reference area and standard certificate

\begin{tabular}{c|c|c|c|c|c|c}
\hline Element & $\begin{array}{c}\text { Earth } \\
\text { Crust }^{8}\end{array}$ & $\begin{array}{c}\text { Referenced } \\
\text { Area }\end{array}$ & $\begin{array}{c}\text { San Joaquim Soil } \\
\text { (Experimental } \\
\text { Values) }\end{array}$ & $\begin{array}{c}\text { San Joaquim Soil } \\
\text { (Certified } \\
\text { Values) }\end{array}$ & Sandy soil $^{7}$ & $\begin{array}{c}\text { Soil in } \\
\text { Japan }^{14}\end{array}$ \\
\hline $\mathrm{Ce}$ & 66 & $0.14 \pm 0.01$ & $0.044 \pm 0.001$ & $0.042 \pm 0.001$ & $21 \pm 1$ & 33 \\
\hline $\mathrm{La}$ & 35 & $14.5 \pm 0.3$ & $0.026 \pm 0.001$ & $0.023 \pm 0.001$ & $3.0 \pm 0.3$ & 15 \\
\hline $\mathrm{Eu}$ & 2.1 & $5.1 \pm 0.3$ & $0.011 \pm 0.001$ & $0.009 \pm 0.001$ & $<0.04$ & 0.8 \\
\hline $\mathrm{Sm}$ & 7 & $4.1 \pm 0.2$ & $0.038 \pm 0.001$ & $0.038 \pm 0.001$ & $0.39 \pm 0.02$ & 3.4 \\
\hline
\end{tabular}

The results obtained by the evaluation of the influence of the phosphogypsum stacks to the surrounding soil (RA) were presented in Table 2 with other results from the literature.

The REE concentration results in RA soil samples were inferior to the values found in other researches, for the Earth's crust, with exception of element $\mathrm{Eu}$, which presented higher concentrations.

In contrast, the RA soil showed heavy REE enrichment, indicating that the stacks have changed in some way the concentration of the elements in the soil under its influence.

Comparing the RA results to the soils found in other researches, it is possible to observe that the
Ce concentration was lower than in the soils from Japan and sandy soils. The $\mathrm{La}$ and $\mathrm{Sm}$ concentrations, however, were close to the values found in Japanese soils and higher than Brazilian sandy soils. On the other hand, the Eu had its concentration higher in the RA than in the other researches, which indicate that there was an increase of the element on this area.

\subsection{Statistical Analysis - Cluster}

Figure 6 shows the result of Cluster analysis using the software STATISTICA 7 (StatSoft Inc.).

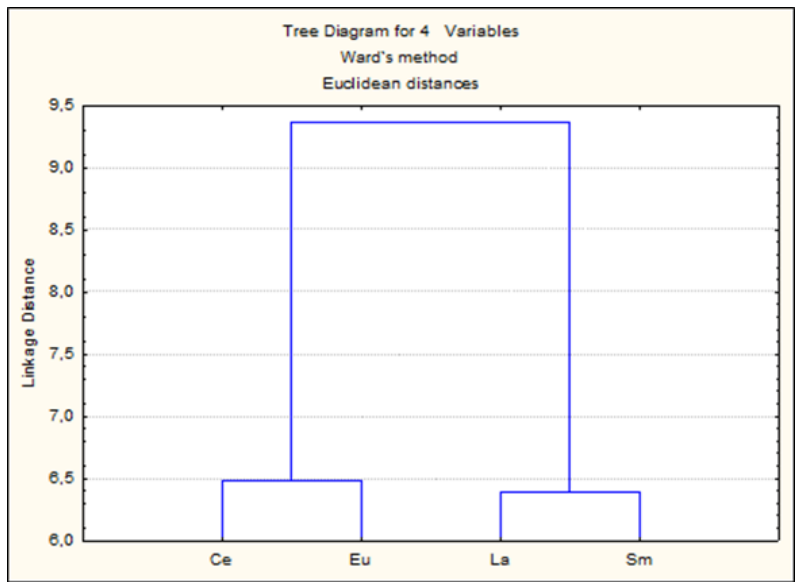

Figure 6. Cluster analysis. 
It is possible to observe that there is the formation of two large similarity groups: first, composed by $\mathrm{Ce}$ and $\mathrm{Eu}$, which presented much higher concentrations in the phosphogypsum than in the Earth's crust; and the second, composed by $\mathrm{La}$ and $\mathrm{Sm}$, whose concentrations were closer to the results obtained for the Earth's crust.

\section{Conclusions}

The result obtained ( $\Sigma$ REE the order of 1366.3 $\mathrm{mg} \mathrm{kg}^{-1}$ ) indicated that the phosphogypsum produced in Imbituba has a high concentration of REE when compared with background values found in environmental samples. High concentration of rare-earths in phosphogypsum suggests that these elements may contaminate animals, plants, rivers, lakes and consequently humans during the ingestion of food grown on soils treated with this phosphogypsum.

Results showed a high concentration of $\mathrm{Ce}$ and Eu and a concentration below the global average of La when compared to igneous rocks from other regions. However, $\mathrm{Eu}$ and $\mathrm{Sm}$ presented values close to those found in phosphogypsum of other regions. This is due to the origin of matrix rock used in the processing, which may vary the concentration of REE in phosphogypsum.

\section{Acknowledgments}

The authors would like to acknowledge the Conselho Nacional de Desenvolvimento Científico e Tecnológico (CNPq) and Coordenação de Aperfeiçoamento de Pessoal de Nível Superior (CAPES) for the scholarship and financial support.

\section{References}

[1] Associação brasileira de normas técnicas. NBR 10006: Solubilização de resíduos, Rio de Janeiro, 1987.

[2] Fernandes, H. M., Rio, A. P. M., Franklin, M. R., Impactos Radiológicos da Indústria do Fosfato, Série Esdutos \& Documentos CETEM/MCT 56 (2004).

[3] Koeberl, O., Bayer, P. M., Concentrations of rare-earth elements in human brain tissue and kidney stones determined by neutron activation analysis, Journal of Alloys Compounds, 180 (1998) $63-70$.

[4] Gorbunov, A. V., Frontasyeva, M. V., Gundorina, S. F., Onischenko, T. L., Maksiuta, B. B., Chen Sen Pal, Effect of agricultural use of phosphogypsum on trace elements in soils and vegetation, Science of the Total Environmental 122 (3) 337-346. https://doi.org/10.1016/0048-9697(92)90051S.

[5] Santos, A. J. G., Mazzilli, B. P., Fávaro, D. I. T., Silva, P. S. C., Partitioning of radionuclides and trace elements in phosphogypsum and its source materials based on sequential extraction methods, Journal of Environmental Radioactivity 87 (2006) 52-61.

https://doi.org/10.1016/j.jenvrad.2005.10.008.

[6] Lebourlegat, F. M., Disponibilidade de Metais em Amostras de Fosfogesso e Fertilizantes Fosfatados Utilizados na Agricultura, 2010, 88f. Dissertação (Mestrado) - Instituto de Pesquisas Energéticas e Nucleares, São Paulo, 2010.

[7] Oliveira, K. A. P., Fator de Transferência de Elementos Terras Raras em Solos Tropicais Tratados com Fosfogesso, 2012, 133f. Tese (Doutorado) - Saneamento, Meio Ambiente e Recursos Hídricos, UFMG, Belo Horizonte, 2012.

[8] Tyler, G., Rare-earth elements in soil and plant system - A review, Plant and Soil. 267 (2004) 191206.

[9] Sneller, F. E. C., Kalf, D. F., Weltje, L., Wezel Van, A. P., Maximum Permissible Concentrations and Negligible Concentrations for Rare Earth Elements (REEs). IVM-National Institute for Public Health and the Environment, report 601501011: The Netherlands, 2000.

[10] Lapido-Loureiro, F. E., Fertilizantes e sustentabilidade: o fósforo na agricultura brasileira, Série de Estudos e Documentos, CETEM, 2008.

[11] Ihlen, P.M., Schiellerup, H., Gautneb, H., Skar, O., Characterization of apatite resources in Norway and their REE potential - A review, Ore Geology Reviews 58 (2013) 126-147. https://doi.org/10.1016/j.oregeorev.2013.11.0 03. 
[12] Fortescue, J. A. C., Landscape geochemistry: retrospect and prospect - 1990, Applied Geochemistry, 7 (1992) 1-53.

[13] Kabata-Pendias, A., Pendias, H., Trace elements in soils and plants, Boca Raton, $2^{\text {rd }}$ ed., 1992.

[14] Uchida, S., Tagami, K., Hirai, I., Soil-to-plant transfer factors of stable elements and naturally occurring radionuclides (1) Upland field crops collected in Japan, Journal of Nuclear Science and Technology 44 (4) (2007) 628-640. https://doi.org/10.1080/18811248.2007.9711851. 